\title{
Российский буддизм и социальные медиа: тувинские буддийские онлайн-сообщества ВКонтакте
}

\author{
Тимур Б. Бадмацыренов, Федор В. Хандаров,
}

Бурятский государственный университет имени Доржи Банзарова, Российская Федерация Дамдин Д. Бадараев,

Институт монголоведения, буддологии и тибетологии СО РАН, Российская Федерация
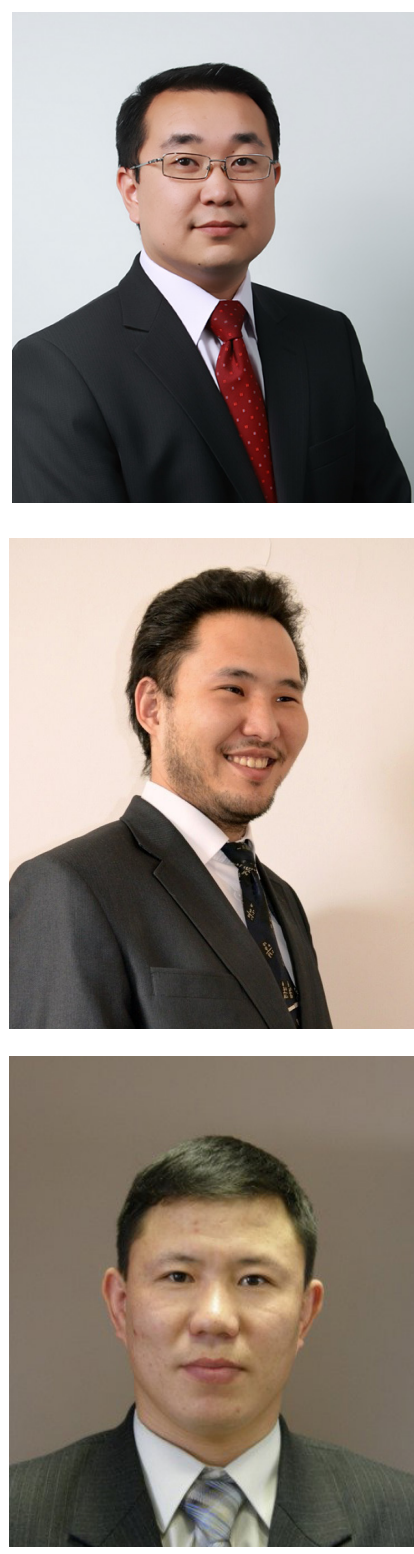

Развитие социальных медиа в последние годы демонстрирует новое измерение соотношения традиции и инновации в религиозной жизни. Социальные медиа стали особым пространством трансформации буддийских сообществ. Оно не ограничивается простым использованием новых информационных технологий, а ставит перед ними сложные вопросы сохранения традиции и адаптации к изменениям, приспособления к глобальной культуре и защиты этнических иенностей.

В статье выявляются особенности использования социальных медиа тувинскими буддийскими онлайн-сообществами в социальной сети ВКонтакте. Одним из самых больших по числу пользователей является сообщество «Сарыг Шажын Тывада» с более 36 тысячами подписчиков, которое входит в число крупнейших буддийских групп в ВКонтакте. Он демонстрирует устойчивый рост пользователей. С использованием специально разработанного программного обеспечения был произведен автоматизированный сбор данных, что позволило построить социальный граф. Его анализ проводился с помощью методов математического моделирования, а именно кластерного анализа и расчета его топологических свойств, коэффициента ассортативности, соответствия степенному закону распределения степеней вершин и степени посредничества.

Тувинские буддийские онлайн-сообщества обладают выраженными этнорелигиозными отличиями, отличаются ориентацией на воспроизводство этнической традиции, использование тувинского языка, сравнительно высокой плотностью социальной коммуникации. Можно предположить, что для многих пользователей участие в таких онлайн-группах выступает одним из механизмов трансляции этничности и приверженности традициям.

Ключевые слова: онлайн-сообщество; буддим; Интернет; религиозное сообщество; Тува; тувинцы; тувинский буддизм

Статья подготовлена при финансовой поддержке Российского фонда фундаментальных исследований, проект № 20-011-00531 «Российский буддизм и социальные медиа: иифровая трансформация буддийских сообществ».

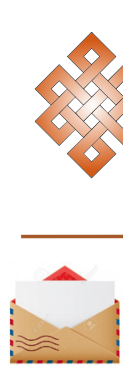

Для цитирования:

Бадмацыренов Т. Б., Хандаров Ф. В., Бадараев Д. Д. Российский буддизм и социальные медиа: тувинские буддийские онлайн-сообщества ВКонтакте // Новые исследования Тувы. 2020, № 4. C. 120-134. DOI: https://www.doi.org/10.25178/ nit.2020.4.9

Бадмацыренов Тимур Баторович - доктор социологических наук, доцент, директор Центра социально-политических исследований «Альтернатива», доцент кафедры политологии и социологии Бурятского государственного университета имени Доржи Банзарова. Адрес: 670000, Россия, г. Улан-Удэ, ул. Смолина, д. 24а. Тел.: +7 (924) 395-95-42. Эл. адрес: batorovitch@mail.ru

Хандаров Федор Владимирович - кандидат технических наук, заведующий лабораторией цифровой экономики Научно-исследовательского центра Института экономики и управления Бурятского государственного университета имени Доржи Банзарова. Адрес: 670000, Россия, г. Улан-Удэ, ул. Смолина, д. 24а. Тел.: +7 (924) 456-31-12. Эл. адрес: fedor.khandarov@gmail.com

Бадараев Дамдин Доржиевич - кандидат социологических наук, старший научный сотрудник отдела истории, этнологии и социологии Института монголоведения, буддологии и тибетологии СО РАН. Адрес: 670047, Россия, г. Улан-Удэ, ул. Сахьяновой, д. 6. Тел.: +7 (924) 651-35-36. Эл. адрес: damdin80@mail.ru 


\title{
Russian Buddhism and social media: Tuvan Buddhist online-communities on Vkontakte
}

\author{
Timur B. Badmatsyrenov, Fedor V. Khandarov \\ Buryat State University, Russian Federation, \\ Damdin D. Badaraev \\ Institute for Mongolian, Buddhist and Tibetan Studies, Siberian branch, RAS, Russian Federation
}

\begin{abstract}
The evolution of social media in recent years has demonstrated a new dimension of the correlation between tradition and innovation in religious life. Social media have become a special transformative space for Buddhist communities, a space which does not limit itself to using new information technologies. It also challenges these communities to preserve tradition and adapt to changes, get involved into global culture, and protect ethnic values.

The article examines the usage of media by Buddhist communities, taking Tuvan online communities on the social network VKontakte as our case study. We will specifically focus on the largest online Tuvan Buddhist VK community "Saryg Shazhyn Tyvada" (36000 users), which shows a steady growth in users. It is also among the largest Buddhism-related communities on this social network. With specially developed software, an automated data collection was carried out, which made possible to build a social graph. The analysis of the graph made use of mathematical modeling, namely, cluster analysis and calculation of its topological properties, assortativeness coefficient, degree distribution of nodes and betweenness degree.

Tuvan Buddhist online communities have pronounced ethno-religious peculiarities, an orientation towards reproducing ethnic tradition, the use of the Tuvan language, and a relatively high density of social communication. It can be assumed that for many users, participation in such online groups is one of the mechanisms for broadcasting ethnicity and adherence to traditions.
\end{abstract}

Keywords: online community; Buddhism; the Internet; religious community; Tuva; Tuvans; Tuvan Buddhism

Financing

The article was prepared with support from the Russian Foundation for Basic Research, Grant No. 20-011-00531

"Buddhism of Russia and Social Media: Digital transformation of Buddhist Communities".

\section{For citation:}

Badmatsyrenov T. B., Khandarov F. V. and Badaraev D. D. Rossiiskii buddizm i sotsial'nye media: tuvinskie buddiiskie onlain-soobshchestva VKontakte [Russian Buddhism and social media: Tuvan Buddhist online-communities on Vkontakte]. New Research of Tuva, 2020, no. 4, pp. 120-134. (In Russ.). DOI: https://www.doi.org/10.25178/nit.2020.4.9

BADMATSYRENOV, Timur Batorovich, Doctor of Sociology, Associate Professor, Chair of Political Science and Sociology; Head, Center for Social and Political Studies, Buryat State University. Postal address: 24a Smolina St., 670000 Ulan-Ude, Russian Federation. Tel.: +7 (924) 395-95-42.E-mail: batorovitch@mail.ru ORCID ID: 0000-0002-6363-9464

KHANDAROV, Fedor Vladimirovich, Candidate of Technical Sciences, Head, Laboratory of Digital Economics, Institute of Economics and Management, Buryat State University. Postal address: 24a Smolina st., 67000 Ulan-Ude, Russian Federation. Tel.: +7 (924) 456-31-12. E-mail: fedor.khandarov@gmail.com ORCID ID: 0000-0002-1506-5697

BADARAEV, Damdin Dorzhievich, Candidate of Sociology, Senior Researcher, Institute for Mongolian, Buddhist and Tibetan Studies, Siberian branch, Russian Academy of Sciences. Postal address: 6 Sakhianova st., 670047 Ulan-Ude, Russian Federation. Tel.: +7 (924) 651-35-36. E-mail: damdin80@mail.ru ORCID ID: 0000-0001-8173-7175 


\section{Введение}

Развитие социальных медиа в последние годы демонстрирует новое измерение соотношения традиции и инновации в религиозной жизни. Социальные медиа стали особым пространством трансформации буддийских сообществ, которая не ограничивается простым использованием новых информационных технологий. Перед ними встают сложные вопросы сохранения традиции, адаптации к изменениям, а также приспособления к глобальной культуре и защиты этнических ценностей. Вследствие этого возникает большое число разнообразных буддийских онлайн-сообществ. В онлайн-пространстве такая множественность цифрового буддизма является продолжением существования «двух буддизмов», как Ч. Пребиш еще в 1979 г. обозначил «параллельное» сосуществование в США традиционных азиатских буддийских общин и сообществ конвертитов ${ }^{1}$ (Prebish, 1979).

В современной России буддийские сообщества представлены во многих формах, от ориентированных на традиции монашества и монастырской организации до инновационных кибербуддийских сообществ. Как отмечает Б. В. Базаров, «буддизм с самого начала был поставлен в сложную ситуацию необходимости отстаивания традиционных ценностей в сочетании с признанием инноваций в области технологий, образования, сферы услуг» (Базаров, 2014: 9). Это особо актуально в свете того, что «буддизм все активнее выходит за рамки своих прежних локально-исторических и национально-географических границ, он охватывает все новые культурные ареалы, т. е. происходит де-территориализация религии, ее транснационализация» (Уланов, 2008: 68).

Цель предлагаемой статьи состоит в выявлении особенностей использования социальных медиа буддийскими сообществами - на примере тувинских онлайн-сообществ в социальной сети ВКонтакте. Для достижения поставленной цели планируется привлечение методов математического моделирования. Данная статья является частью проекта «Российский буддизм и социальные медиа: цифровая трансформация буддийских сообществ», поддержанного грантом Российского фонда фундаментальных исследований, в котором исследуются то, какое влияние оказывает на буддийские идеи и практики использование буддийскими сообществами социальных медиа. В предшествующих статьях нами были описаны различные аспекты развития буддийских онлайн-сообществ, но вопросы развития тувинских онлайн-сообществ нами прежде отдельно не рассматривались (Актамов, Бадмацыренов, Цыремпилов, 2015; Бадмацыренов, Скворцов, Хандаров, 2018ab; Актамов, Бадмацыренов, Хандаров, 2018).

Теоретико-методологическая база работы включает теорию медиатизации религии и новый подход в изучении взаимодействия религии, Интернета и новых медиа с центральным концептом «цифровая религия». В своей работе мы используем концепцию социорелигиозного форматирования технологий Х. Кэмпбелл (Campbell, 2013).

\section{Развитие подходов в исследовании буддийских онлайн-сообществ}

Теоретические рамки исследования религии в Интернете развивались от изучения «кибер-религии», как религиозных практик, появившихся в компьютерных сетях (O’Leary, 1996), к «виртуальной религии», в призму которой попадали различия между «реальными» и новыми «виртуальными» религиозными структурами (Religion and cyberspace, 2005). В настоящее время активно развиваются исследования смешения онлайн и офлайн религиозных практик и сообществ и возникновения на этой основе гибридных форм «цифровой религии» (Campbell, 2013). В таком видении в интернет-пространстве и связанной с ним офлайн-деятельности происходит развитие новых форм религии, на которые оказывают воздействие и офлайн, и онлайн, а религиозные сообщества не только оказываются перед вызовами цифровой среды, но и активно ее трансформируют.

Х. Кэмпбелл и Дж. Эволви выделяют четыре волны в развитии междисциплинарного исследовательского направления «цифровая религия» (Campbell, Evolvi, 2020). В 90-е годы XX века появились первые исследования «киберрелигии» как результата влияния информационных технологий и компьютерных сетей на религиозное поведение (O’Leary, 1996). В работах второй волны внимание было обращено на противоречия между реальным и виртуальным «пространствами», следствием которых виделось возникновение «виртуальной религии» и виртуальных религиозных сообществ и практик, существовавших только в «киберпространстве» и не соответствовавших «реальной» религии (Religion and cyberspace, 2005). К. Хэлланд предложил идею о различиях между онлайн-религией и религией онлайн для отражения различающихся способов религиозного использования Интернета (Helland,

\footnotetext{
${ }^{1}$ Конвертитами называют лиц, переходящих из одной религиозной конфессии в другую.
} 
2005: Электр. ресурс). Он обратил внимание на гибкость и «текучесть» онлайн-религии, в которой происходило неограниченное взаимодействие между пользователями и возникали новые формы религиозности и интерактивных религиозных онлайн-практик. Религия онлайн, по его мнению, скорее включала формы онлайн-активности традиционных религиозных организаций и была направлена на информирование пользователей об их офлайн-деятельности.

На третьем этапе, по мнению Х. Кэмпбелл, превалировал подход к изучению «цифровой религии» как гибридного смешения онлайн и офлайн религиозных пространств (Campbell, 2016: 3). В таком видении в Интернете и связанной с ним офлайн-деятельности происходит формирование новых форм религии, на которые оказывают воздействие и офлайн, и онлайн, а религиозные сообщества не только оказываются перед вызовами цифровой среды, но и активно ее трансформируют.

Четвертая волна исследований цифровой религии связана с изучением повседневных религиозных медиапрактик людей (Campbell, Evolvi, 2020: 7). Фокус в них по-прежнему сконцентрирован на смешении онлайн и офлайн практик, но внимание уделяется также вопросам политики, этики, гендера, этничности и т. д.

Ключевым элементом описания цифровой религии является исследование того, как люди объединяются в религиозные онлайн-сообщества, ставшие новыми социальными формами религии в социальных медиа. Эти сообщества представляют собой систему взаимодействий между пользователями сетевых цифровых устройств, интернет-сайтов, сетевых платформ и мессенджеров, ориентированных на религиозные идеи, символы и практики. В начале 1990-х годов для обозначения социальных объединений, создающих и развивающих взаимодействия посредством компьютерных сетей, ведущих публичные обсуждения, достаточно длительные для формирования «сетей личных отношений», появился термин «виртуальные сообщества» (Rheingold, 1993: 5). Х. Кэмпбелл под сетевым религиозным сообществом понимает сеть социальных отношений, интегрированную набором общих жизненных практик, устанавливаемых и воспроизводящихся через разделяемую историю. Общее понимание религиозных идей создает разделяемую членами сообщества основу для смыслополагания, в качестве ядра которого выступает общая вера и поиск смыслов и целей в свете различных интерпретаций жизни и реальности. Х. Кэмпбелл описывает их как систему множественных онлайн и офлайн взаимодействий между индивидами и сообществами, новыми и старыми источниками авторитета и легитимности, публичностью и приватностью, в которых люди оказываются в пересечении многих религиозных сетей и смыслов (Campbell, 2010: 96).

В зарубежных буддологических исследованиях изучение буддизма в Интернете стало одним из наиболее перспективных направлений с весьма обширной тематикой, и многие монографии и сборники статей, посвященные изучению истории и современного состояния буддизма, включают разделы о буддизме в Интернете (Prebish, 2004; Schlutter, 2014; Connelly, 2015; Grieve, Veidlinger, 2016). В целом, новые буддийские медиатехнологии включают веб-сайты, виртуальные миры, мобильные приложения и видеоигры (Connelly, 2015). По мнению Г. Грива и Д. Ведлингера, от прежних медиа, использовавшихся буддизмом, современные цифровые технологии отличают процедурные, партиципаторные, энциклопедические и пространственные аффордансы, признаки того, что с объектом можно производить какие-либо действия (Grieve, Veidlinger, 2016: 474). Другими словами, в цифровом пространстве создаются новые формы и паттерны действий верующих, оно позволяет им участвовать в коллективных действиях и сообществах, получать свободный доступ к огромному и постоянно растущему массиву информации и позиционироваться в пространстве и времени.

Уже в 1994 г. Г. Рэй предложил термин «киберсангха» для обозначения новых интернет-форм объединений верующих (Ray, 1994: 60). Ч. Пребиш в 2004 г. выделил три типа буддийских виртуальных сообществ (Prebish, 2004: 145). Первый охватывает веб-страницы традиционных буддийских групп для удобства коммуникации и передачи информации. Второй тип представляет «виртуальные храмы», созданные традиционными сангхами для дополнения своих существующих оффлайн программ и храмов. Третий же представлен «чистыми онлайн-сообществами», не существующими оффлайн. М. Шлуттер выделяет два типа буддийских ресурсов: первый включает веб-сайты, созданные традиционными («доцифровыми») буддийскими центрами, обладающими физически местами для встреч, медитаций, обсуждений и т. п. Второй тип - это сайты, преимущественно обслуживающие интернетсообщества, полностью нового типа «киберсангхи», участники которых редко или совсем не встречаются лицом к лицу (Schlutter, 2014: 511).

В настоящее время исследователями отмечается, что провести точные границы между этими типами сообществ затруднительно, поскольку многие традиционные сообщества расширяют свое вир- 
туальное присутствие, а прежде исключительно виртуальные порождают реальные социальные группы и общины. Вместе с тем, в российском случае, особенно в социальных медиа, можно провести выделить онлайн-группы, созданные буддийскими религиозными организациями, существующими офлайн, объединяющими людей, вступающих в непосредственное взаимодействие. Другую группу составили онлайн-сообщества, для которых нет офлайн-аналогов, они представляют собой форму онлайн-коммуникаций пользователей сетей.

\section{Буддийские сообщества в социальной сети ВКонтакте}

Российская социальная сеть ВКонтакте (vk.com) является одним из крупнейших по посещаемости сайтов в мире и наиболее популярным среди русскоговорящих пользователей. Она была запущена 10 октября 2006 г. и сначала ориентировалась на студентов и выпускников вузов России, но уже в 2007 г. стала позиционироваться как «универсальное средство поиска и связи между людьми, которое в силу своей идеи не может ограничиваться отдельной социальной прослойкой или возрастной группой»1. ВКонтакте характеризуется более молодой аудиторией сравнительно с иными социальными сетями. На начало сентября 2020 г. 89 языковых версий ВКонтакте насчитывали 97 миллионов пользователей в месяц, 13 миллиардов сообщений в сутки ${ }^{2}$.

При заполнении информации профиля, пользователь имеет возможность указать свое мировоззрение, в качестве которого выступает, по сути, отношение к религии: иудаизм, православие, католицизм, протестантизм, ислам, буддизм, конфуцианство, светский гуманизм, пастафарианство. В сентябре 2020 г. число профилей, в которых в качестве мировоззрения был указан буддизм, составило 584651.

В этой социальной сети создано большое число буддийских онлайн-сообществ, которые характеризует довольно большое разнообразие. В сентябре 2020 г. по запросу «буддизм» в поисковой системе ВКонтакте получены результаты о 539 группах. Вместе с тем, поиск и обнаружение буддийских онлайнсообществ в рамках данного исследования не ограничивается только этим запросом и основан на использовании специально разработанного поискового словаря, что позволило получить информацию об около тысячи сообществ.

Ниже представлены результаты запросов в поисковой системе ВК по разработанному нами в ходе исследования перечню. В данной таблице представлены данные об изменении числа подписчиков наиболее крупных групп ВК буддийской направленности с 2015 года, когда был начат данные проект, до настоящего времени.

Таблица 1. Число подписчиков у 11 наиболее крупных буддийских сообществ ВКонтакте в 2015, 2017, 2019,2020 г2.

Table 1. The number of subscribers that 11 largest Buddhist communities on VKontakte had in 2015, 2017,2019 and 2020.

\begin{tabular}{|c|c|c|c|c|c|}
\hline \multirow{2}{*}{$N^{o}$} & \multirow{2}{*}{ Наименование группы ВК } & \multicolumn{4}{|c|}{ Число подписчиков } \\
\hline & & 2015 & 2017 & 2019 & 2020 \\
\hline 1 & Дзэн-буддизм & 312532 & 336269 & 360862 & 368229 \\
\hline 2 & $\begin{array}{l}\text { Драгоценные советы Его Святейшества Далай- } \\
\text { Ламы }\end{array}$ & 182546 & 210427 & 228719 & 231215 \\
\hline 3 & Будда • Учение Будды • Буддизм & 55628 & 82414 & 97860 & 102265 \\
\hline 4 & Буддизм & - & 38081 & 41307 & 42079 \\
\hline 5 & Тибетский буддизм & - & 18699 & 26522 & 31729 \\
\hline 6 & $\begin{array}{l}\text { Буддизм Будда Дхамма Сангха Тхеравада // } \\
\text { «Буддаяна. Будда. Дхамма. Сангха. Буддизм» }\end{array}$ & 17260 & 16208 & 16140 & 16518 \\
\hline
\end{tabular}

\footnotetext{
1 Дуров П. В Контакте миллион участников [Электронный ресурс] // ВКонтакте. 2007, 17 июля. URL: https:// vk.com/blog.php?nid=54 (дата обращения: 12.09.2020).

${ }^{2}$ Соединяем людей, сервисы и компании [Электронный ресурс] // ВКонтакте. URL: https://vk.com/about (дата обращения: 12.09.2020).
} 


\begin{tabular}{|l|l|c|c|c|c|}
\hline 7 & Хамбо Лама Даши-Доржо Итигэлов & 16274 & 23708 & 29663 & - \\
\hline 8 & Сарыг Шажын Тывада & 15328 & 26730 & 35061 & 36161 \\
\hline 9 & $\begin{array}{l}\text { Санкт-Петербургский Дацан Гунзэчойнэй | } \\
\text { Буддизм }\end{array}$ & 13977 & 22191 & 31936 & 35961 \\
\hline 10 & Буддизм|Махаяна|Гелуг & 11546 & 18061 & 27260 & 29977 \\
\hline 11 & Карма Кагью | Буддизм Алмазного пути & 10823 & 14441 & 17177 & 16678 \\
\hline
\end{tabular}

Можно отметить, что среди них представлены сообщества, ориентированные на обобщенных «буддийских» пользователей, вне привязки к конкретному направлению, школе или этнокультурной форме. Среди них довольно существенно выделяется «Дзэн-буддизм» ${ }^{1}$, как по числу пользователей, так и по содержанию и направленности материалов, содержащих преимущественно цитаты из дзенских сочинений или околодзенских публикаций. Ведут эту группу профессиональные SMM-менеджеры, предлагающие ее для размещения рекламы в разделе «Эзотерика, Астрология, Самопознание, Йога»². Вообще, в ВКонтакте насчитывается большое число групп, использующих в названии слова «дзен» и «Дзэн», большая часть из которых тематически не связана с буддизмом. Это отражает большую популярность концепта «дзэн» как явления массовой культуры, связанного с буддийской культурой лишь частично. Часть групп «дзэн» при этом все-таки посвящены изучению наследия дзэн-буддизма и культуры Японии, хотя уступают первым («дзен») по популярности.

Другие сообщества в представленном списке - «Будда. Учение Будды. Буддизм» и «Буддизм» - направлены на «всё многообразие направлений буддизма» и в них представлено «большое количество качественного материала по теоретическим и практическим аспектам дхармы»³. Пользователи могут принять участие в обсуждении различных вопросов буддийской философии и практики, так, например, в группе «Буддизм» создано более 200 обсуждений, включая такие темы как: «Тхеравада и тибетский буддизм», «Как правильно медитировать?», «Читаем сутры» и т. д. По своей тематике и направленности эти группы весьма близки к прежним буддийским форумам, появившимся еще в 1990-е годы, наиболее популярными среди которых были «Буддийский форум» ${ }^{4}$ «Дхарма Буддийское сообщество» ${ }^{5}$ В целом они характеризуются «общебуддийской» направленностью на последователей буддизма и/или интересующихся буддийской культурой и философией.

Среди популярных групп представлены несколько сообществ с выраженной ориентацией на школу или направление. Группа «Драгоценные советы Его Святейшества Далай-Ламы» представляет собой элемент медиа-комплекса Далай-ламы XIV Тензина Гьятсо, включающего официальный сайт, профили в Инстраграм, Фейсбуке и ВК-страницуб и другие сайты, которые сопровождаются Фондом содействия сохранению культурных и философских традиций тибетского буддизма «Сохраним Тибет» под духовным руководством Тэло Тулку Ринпоче и Офисом Его Святейшества Далай-ламы XIV. На них пользователи могут получить информацию о многогранной деятельности Его Святейшества, его учениях, мероприятиях с его участием. Связанное с ними сообщество «Тибетский буддизм», как заявлено в нем, «объединяет (в пределах этого ресурса) людей, которым интересны и близки теория и практика традиций буддизма, которые развивались в Тибете и далее в Монголии и буддийских республиках РФ: Бурятии, Калмыкии, Тыве 7 . Это распространённые ныне Ньингма, Гелуг, Кагью и Сакья» ${ }^{8}$ Ведется эта группа представителями Буддийского центра «Арьядэва» Фонда поддержки махаянской традиции.

Два сообщества в представленном списке связаны с бурятскими буддийскими сообществами. Группа «Буддизм|Махаяна|Гелуг» была основана Этигел-ламой Жамсарановым, одним из бурятских

\footnotetext{
${ }^{1}$ https://vk.com/dzyen

${ }^{2}$ https://vk.com/@victoria_les_media-prais-red-fox-media

${ }^{3}$ https://vk.com/public.buddha

${ }^{4}$ http://board.buddhist.ru/

${ }^{5}$ http://dharma.org.ru/

${ }^{6}$ https://vk.com/dalailama

${ }^{7}$ Правильно «Туве». - ред.

8 https://vk.com/tibetan_dharma
} 
буддийских священнослужителей, и значительная доля материалов направлена на бурятских верующих. Сообщество «Хамбо Лама Даши-Доржо Итигэлов» было описано нами в одной из статей, но, к сожалению, сейчас оно не существует (Бадмацыренов, Скворцов, Хандаров, 2018а). Среди более двадцати тысяч его подписчиков были представители разных этнических групп, включая бурят, тувинцев, калмыков, русских и других (там же).

Особое место в онлайн-пространстве российского буддизма занимает группа «Санкт-Петербургский Дацан Гунзэчойнэй | Буддизм» . Во-первых, она создана в качестве группы буддийского дацана-монастыря, который располагается в Санкт-Петербурге, вне регионов традиционного распространения российского буддизма. Во-вторых, она объединяет буддийских священнослужителей и мирян из разных регионов нашей страны и из-за рубежа, что отражает открытость Санкт-Петербургского дацана для буддистов разных направлений.

Группа «Карма Кагью | Буддизм Алмазного пути»² представляет собой центральную ВК-группу для целого ряда групп последователей Российской Ассоциации Буддистов Алмазного Пути Традиции Карма Кагью, международной буддийской организации, созданной буддийским учителем датского происхождения Оле Нидалом.

Группа «Буддаяна. Будда. Дхамма. Сангха. Буддизм»³ содержит «контент на тему Раннего Буддизма и Первоначального учения Будды Гаутамы (Саддхамма), - каким оно сохранено и представлено в современной южной палийской традиции буддизма Тхеравада» ${ }^{4}$. Это сообщество является самым крупным среди «тхеравадинских» групп, ядром которых является сайт Тхеравада.ру ${ }^{5}$, созданный СанктПетербургской общиной буддистов Тхеравады, самым известным представителем которой является буддийский монах тайской традиции русского происхождения Бханте Панньяавудхо.

Все сообщества этих категорий существуют исключительно в форме онлайн-сообществ. Исключение составили лишь группы «Санкт-Петербургского дацан Гунзэчойнэй», «Буддаяна. Будда. Дхамма. Сангха. Буддизм» и «Карма Кагью | Буддизм Алмазного пути», поскольку для них есть соответствующие офлайн-общины, члены которых находятся в непосредственном взаимодействии.

\section{Тувинские буддийские онлайн-сообщества в ВКонтакте}

В таблице 2 представлены наименования и число подписчиков сообществ ВКонтакте, посвященных буддизму в Туве. В ходе нашего исследования мы обнаружили таковых 24. Большая часть из них открыта для любого пользователя BK, но некоторые имеют ограниченный доступ только для зарегистрированных членов. Можно отметить наличие сравнительно крупных групп, что отражает популярность буддийских идей и ценностей среди тувинских пользователей. Как в 2014 г. отметила модератор нескольких крупных тувинских пабликов ВК, в том числе буддийской направленности, О. С. Дамдын, «в соцсетях помимо негатива присутствует много позитива. Есть сообщества, в которые вступают настоящие патриоты» ${ }^{6}$.

Таблица 2. Тувинские буддийские сообщества ВКонтакте Table 2. Tuvan Buddhist communities on VKontakte.

\begin{tabular}{|l|l|c|}
\hline № & Название & Число подписчиков \\
\hline 1 & Сарыг Шажын Тывада & 35331 \\
\hline 2 & САРЫГ ШАЖЫН | ЧОННУН ШИЛИЛГЕЗИ | ТЫВА| ТУВА & 7680 \\
\hline 3 & DНАRМА ТYVА «Сарыг Шажын Тывада» & 3760 \\
\hline
\end{tabular}

${ }^{1}$ https://vk.com/dazanspb

${ }^{2}$ https://vk.com/russiankagyu

${ }^{3}$ https://vk.com/buddha_dhamma

${ }^{4}$ https://vk.com/buddha_dhamma

${ }^{5}$ http://www.theravada.ru/

${ }^{6}$ По итогам конкурса эссе «100 новых идей развития Тувы» будут назначены новые министры [Электронный ресурс] // ИА Туваонлайн. 2014, 1 декабря. URL: https://www.tuvaonline.ru/2014/12/01/po-itogam-konkursa-esse100-novyh-idey-razvitiya-tuvy-budut-naznacheny-novye-ministry.html (дата обращения: 09.09.2020).

${ }^{7}$ Данные представлены на сентябрь 2020 г. Наименования групп даны с сохранением оригинальной орфографии и пунктуации. 


\begin{tabular}{|c|c|c|}
\hline 4 & Буддийский центр «Манджушри» г. Кызыл & 2327 \\
\hline 5 & Группа Дост. Шивалха Ринпоче & 1178 \\
\hline 6 & Шажынчы өңнүктеривис & 1099 \\
\hline 7 & Сарыг шажын чудулгевис & 455 \\
\hline 8 & Эрзин кожуун сарыг шажын!!!! ओम मनी पद्म & 318 \\
\hline 9 & Этно-культурный комплекс «Белдир-Кежии» & 147 \\
\hline 10 & Сарыг-Шажын & 32 \\
\hline 11 & Манджушри аттыг Сарыг шажын төву & 30 \\
\hline 12 & Норбулинг & 259 \\
\hline 13 & Москвада «Субедей» агымының салбыры & 112 \\
\hline 14 & ХУрээ «ШЕДУП ДАРЖАЛИН» & 131 \\
\hline 15 & Фестиваль живой музыки и веры «Устуу-Хурээ» & 136 \\
\hline 16 & Хурээ «Дамба Брайбулинг» & 143 \\
\hline 17 & Те которые ходит в хурээ ЦЕЧЕНЛИНГ & 168 \\
\hline 18 & хүрээ Ташипандэлиң (хурээ) & 108 \\
\hline 19 & Авыда хурээ & 49 \\
\hline 20 & Ногаан Дарийги хурээ & 49 \\
\hline 21 & Буддаяна / Тхеревада. Буддизм в Кызыле & 54 \\
\hline 22 & $\begin{array}{l}\text { Молодые ученики Досточтимого Геше Джампа Тинлея из } \\
\text { Республики Тыва }\end{array}$ & 76 \\
\hline 23 & Фонд буддийского храма в с. Хову-Аксы & 51 \\
\hline 24 & Буянныг Өөредиг | Учение Будды в Туве & 3 \\
\hline
\end{tabular}

Обращает на себя внимание то, что наиболее крупные сообщества не связаны с офлайн-общинами, в то время как группы хурээ и буддийских центров сравнительно немногочисленны. Так, группа «Буянныг Өөредиг | Учение Будды в Туве» предположительно была создана в 2019 г. для сопровождения деятельности Управления Камбы-ламы Республики Тыва и связана с официальным сайтом Управления, но крайне немногочисленна и неинформативна. Стоит отметить, что по инициативе Управления Камбы-ламы еще в 2009 г. был создан сайт dharma.tuva.ru - для «освещения работы и жизни тувинского буддийского сообщества, который до сих пор был в информационной изоляции от внешнего мира. Немаловажной целью является объединение различных направлений деятельности буддистов, которое будет реализовано в рамках сайта» ${ }^{2}$. Но он недолго просуществовал и в настоящее время сайт не функционирует. В целом, надо отметить сравнительно невысокие темпы продвижения буддийских общин Тувы в Интернете, несмотря на то, что еще в 2014 г. Камбы-Лама Республики Тыва Лопсан Чамзы «сделал упор на более широком использовании средств Интернета для духовного просвещения верующих и усиления работы с населением, направленной на преодоление проблем,

${ }^{1}$ У буддистов Тувы появился свой сайт dharma.tuva.ru [Электронный ресурс] // Сохраним Тибет! 2009, 2 сентября. URL: http://savetibet.ru/2009/09/02/tuva.html (дата обращения: 09.09.2020). 
связанных с духовным и физическим здоровьем» ${ }^{1}$ В настоящее время медиадеятельность Управления Камбы-ламы Республики Тыва опирается на официальный сайт https:/tuvalobdon.com/.

Группа «Фестиваль живой музыки и веры «Устуу-Хурээ»² посвящена фестивалю, который проводится с 1999 г. в г. Чадане Республики Тыва. Организаторами фестиваля выступают Министерство культуры Республики Тыва, Тувинская государственная филармония им. В. М. Халилова и Тувинское республиканское общественно-творческое объединение «Устуу-Хурээ»³. Вместе с тем, в наименовании группы содержится название буддийского монастыря, а сам фестиваль посвящен возрождению уникального буддийского храмового комплекса Устуу-Хурээ, разрушенного в 1937 г.

Также можно отметить существование групп, ориентированных на разные офлайн-общины. С конца 1980-х гг. буддизм в Туве занимает место «главной религии верующих и имеет прекрасные перспективы дальнейшего развития и укрепления» (История буддизма ..., 2011: 130). Вместе с тем, наряду с буддийским духовенством, в регионе все более активную роль играют сообщества буддистов-мирян, которые в ряде случаев выступают с критикой Управления Камбы-ламы (Монгуш, 2001: 136). Это создает ситуацию, похожую, по образному выражению Ольги Матпаевны Хомушку, на «лоскутное одеяло, когда каждый центр или община считает только себя “истинными буддистами”» (Хомушку, 1998: 77). Эта метафора вполне применима и к описанию онлайн-сообществ в социальных сетях, где возникает довольно большое их разнообразие. В настоящее время, по оценке деятельности тувинского буддийского духовенства, которую дает исследователь и руководитель тувинского общества «Друзья Тибета» Ч. М.-Х. Тензин, «активное строительство буддийских сооружений способствует укреплению единства тувинского народа, повышению буддийской культуры, духовному развитию тувинского населения и уменьшению социальных проблем, конфликтов и напряженности в тувинском обществе» (Тензин, 2018: 93).

Некоторые онлайн-сообщества созданы как цифровые двойники буддийских хурээ и их общин, но по числу подписчиков они значительно уступают другим тувинским буддийским онлайн-сообществам. Это обусловлено, вероятнее всего, тем, что хурээ ориентированы на локальные, сравнительно немногочисленные, группы, которые не используют их в коммуникации, предпочитая непосредственное участие в религиозных мероприятиях и общение со священнослужителями и верующими. Возможно, также, что верующими в локальных общинах хурээ для связи используются все более набирающие популярность на волне распространения смартфонов и мобильного интернета мессенджеры, объединяющие преимущественно группы людей, вступающих в непосредственное взаимодействия, причем можно предположить, что это чаты в Viber, поскольку именно он является наиболее популярным мессенджером в регионе ${ }^{4}$. В России пока не предпринималось изучение особенностей использования мессенджеров в буддийских сообществах, учитывая труднодоступность их аудитории для исследователей.

В ВКонтакте создан ряд групп, объединяющих активистов и сторонников в разных городах молодежного буддийского движения «Субедей». Оно возглавляется монахом Шолбаном Иргитом, обучавшемся в индийском монастыре Гоман дацан. Объединяет несколько сот человек (Тарбастаева, 2018: 105).

Также две группы в списке представляют собой онлайн-сообщества тувинских учеников геше Джампа Тинлея, известного буддийского учителя, и являются частью разветвленной сети центров и общин под его руководством.

\section{Анализ онлайн-сообщества «Сарыг Шажын Тывада»}

В рамках исследования мы изучили онлайн-сообщество «Сарыг Шажын Тывада» (досл. «Желтая религия в Туве» или «Тувинский буддизм») ${ }^{5}$, которое демонстрирует устойчивый рост пользователей

\footnotetext{
${ }^{1}$ Буддизм [Электронный ресурс] // Агентство по делам национальностей Республики Тыва. URL: нацполитикатыва.pф/religii/buddizm/ (дата обращения: 09.09.2020).

${ }^{2}$ https://vk.com/ustuhure

${ }^{3}$ http://ustuhure.com/index.php/festival-ustuu-khuree

${ }^{4}$ Самый популярный мессенджер по регионам России [Электронный ресурс] // Яндекс.Дзен. 2019, 13 ноября. URL: https://zen.yandex.ru/media/map_mind/samyi-populiarnyi-messendjer-po-regionam-rossii5 dcc1f02c3cd3c2757f666fa

${ }^{5}$ https://vk.com/public.sarygshajin
} 
с 15328 в 2015 г. до 36000 - в 2020 г. Оно является крупнейшим онлайн-сообществом ВКонтакте, объединяющим тувинских буддистов, поэтому рассмотрение его дает важные заключения.

Для изучения структуры сообщества подписчиков группы ВКонтакте «Сарыг Шажын Тывада» были привлечены методы анализа графов. Эти методы получили широкое распространение в исследованиях сложных сетей, к числу которых относятся и социальные медиа (Newman, Barabasi, Watts, 2006). Применение математического моделирования с использованием современных программных средств автоматизированного сбора и анализа данных все более широко применяется в социально-гуманитарных исследований, поскольку позволяет исследовать крупные компьютерные сети с большим числом участников (вершин) и связей (ребер) (Батура, 2012: 13).

В рамках исследования был рассмотрен социальный граф подписчиков данного сообщества, в котором в качестве вершин графа представлены аккаунты пользователей, а в качестве ребер - бинарное отношение их дружбы. Отметим, что анализируемый граф строится на данных, предоставляемых посредством API VK (поисковой системы ВКонтакте), то есть данные заведомо не являются полными: чтобы информация о наличии ребра (то есть о взаимной дружбе) была учтена, необходимо наличие открытого профиля хотя бы у одного из двух пользователей. Всего в полученном графе представлена информация о 36013 вершинах и 374359 ребрах.

Анализ полученного социального графа проводился с помощью методов математического моделирования, а именно, кластерного анализа и расчета его топологических свойств, коэффициента ассортативности, соответствия степенному закону распределения степеней вершин и степени посредничества (Schaeffer, 2007).

В графовых моделях коэффициент ассортативности используется в анализе связей между вершинами различных степеней (Newman, 2003; Ostroumova-Prokhorenkova, Krot, 2016). Другими словами, в ассортативных сетях популярные вершины будут связаны друг с другом напрямую, а в диссассортативных - через цепочки друзей.

Ассортативность рассматриваемого графа близка к нулю и равна 0,0575.

В таблице 1 перечислены некоторые сети, для которых в работе (Newman, 2003) рассчитаны показатели ассортативности. Эти данные часто используются для иллюстрации следующей закономерности: для социальных сетей характерны значения ассортативности большие 0 , для технологических сетей сравнимые с 0, для биологических сетей - меньшие 0.

Сеть подписчиков сообщества «Сарыг Шажын Тывада», таким образом, относится, скорее к технологическим или даже биологическим, а вовсе не к социальным сетям. Примечательно, что сеть пользователей ВКонтакте, указавших «буддизм» в качестве мировоззрения, также имеет показатель ассортативности близкий к 0 .

Таблица 3. Сравнение значения коэффищиента ассортативности для различных сетей

Table 3. Comparison of assortativity quotients for various networks

\begin{tabular}{|c|c|c|c|}
\hline \multirow{2}{*}{ Tuп сети } & Сеть & Количество узлов & Acсортативность \\
\hline Социальные & Соавторство по физике & 52909 & 0,363 \\
\hline Социальные & Сотрудничество директоров & 7673 & 0,276 \\
\hline Социальные & Сотрудничество актеров кино & 449913 & 0,127 \\
\hline Социальные & Соавторство по биологии & 1520251 & 0,12 \\
\hline Социальные & Соавторство по математике & 253339 & 0,092 \\
\hline Социальные & Книга адресов электронной почты & 16881 & 0,0166 \\
\hline
\end{tabular}




\begin{tabular}{|c|c|c|c|}
\hline Технологические & Сеть электростанций & 4941 & $-0,003$ \\
\hline Биологические & Сеть сообщества дельфинов & 62 & $-0,044$ \\
\hline & $\begin{array}{c}\text { «дужба» подписчиков группы } \\
\text { ВКонтакте «Сарыг Шажын Тывада» }\end{array}$ & 36013 \\
\hline Технологические & «Вемирная паутина» (WWW) & 269504 & $-0,067$ \\
\hline Биологические & Сеть взаимодействий белков & 2115 & $-0,156$ \\
\hline Технологические & Интернет & 10697 & $-0,189$ \\
\hline Биологические & Нейронная сеть & 307 & $-0,226$ \\
\hline Биологические & Метаболическая сеть & 765 & $-0,263$ \\
\hline Биологические & Морская пищевая сеть & 134 & $-0,326$ \\
\hline Биологические & Пресноводная пищевая сеть & 92 & \\
\hline
\end{tabular}

Другая важная характеристика в исследовании сетей - соответствие степенному закону распределения степеней вершин. Степенью называется число связей вершины с другими вершинами. $\mathrm{B}$ данном случаe $\log -\log$ график аппроксимируется уравнением $\mathrm{y}=17262 \cdot \mathrm{x}-1.547$ с точностью $\mathrm{R} 2=$ 0,8318 . Для сравнения на графике отложена также линия тренда $\mathrm{y}=17262 \cdot \mathrm{x}-1.547$. Такое распределение показывает, что у большинства участников сообщества малое число связей внутри него, но среди них также присутствует некоторое число популярных пользователей, обладающих большим числом связей с другими пользователями сообщества. Это позволяет трактовать данное сообщество как безмасштабную сеть, схожую по своим свойствам с иными сетями.

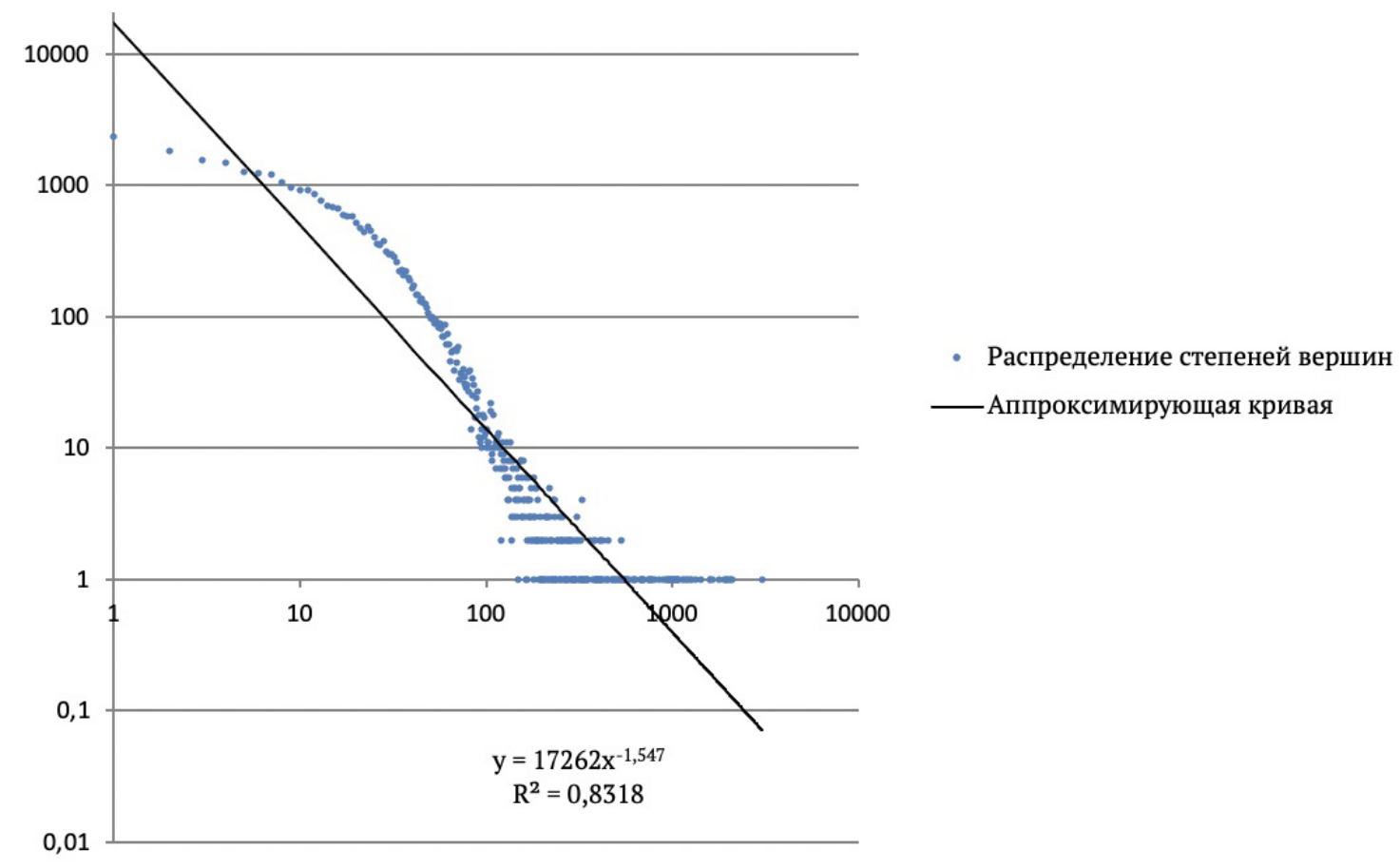

Рисунок 1. $\log -\log$ диаграмма распределения степеней вершин. Fig. 1 A log-log diagram of node degree distribution 
Кластеризация графа, позволила выделить 8 кластеров, в совокупности покрывающих 97,87\% пользователей.

На рисунке 1 представлен социальный граф пользователей сообщества «Сарыг Шажын Тывада». Кластеризация данного графа, полученная путем максимизации функционала модулярности, дает хорошо трактуемые результаты. Прежде всего, следует отметить, что сообщество пользователей распалось на восемь кластеров, что отражает его сложную социальную структуру, элементами которой стали, по всей видимости, профессиональные, территориальные и родственно-клановые сообщества. Можно отметить необходимость дальнейшего изучения переноса в онлайн-пространство внутриэтнических, родоплеменных, этнотерриториальных и семейно-клановых социальных связей. Ч. К. Ламажаа, характеризуя постсоветское развитие Республики Тыва, пишет, что в регионе произошел возврат к архаизации социальных отношений на всех уровнях и актуализации родоплеменных связей (Ламажаa, 2010: 128). Можно предположить, что в религиозных онлайн-сообществах этот процесс также находит свое отражение.

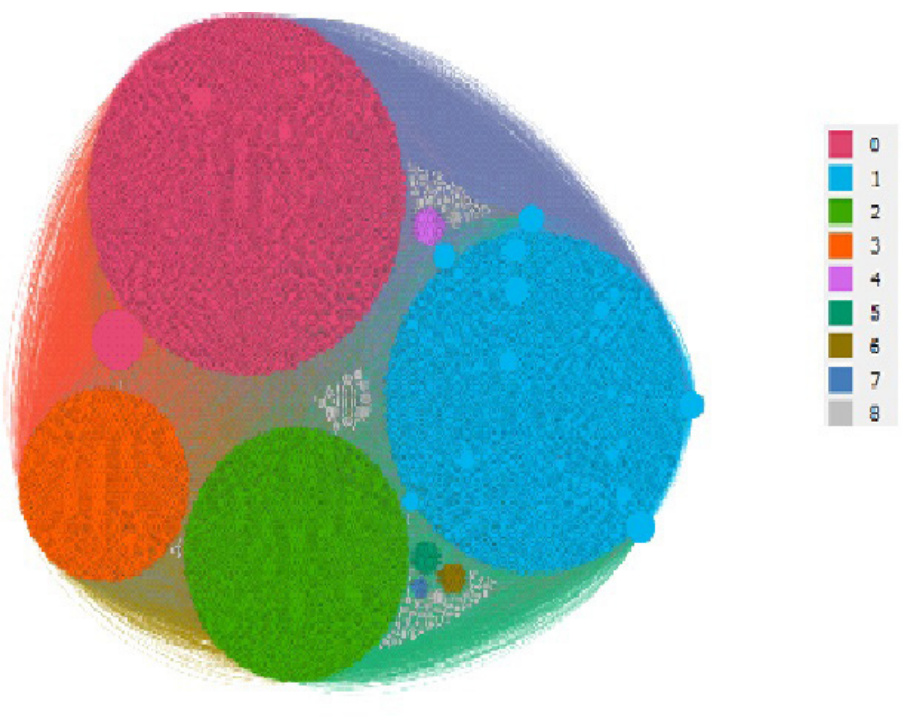

Рисунок 2 Кластеры сообщества подписчиков «Сарыг Шажын Тывада» ВКонтакте. Fig.2. Clusters of the subscribers of Saryg Shazhyn Tyvada community on VKontakte

Помимо степени (количество друзей внутри графа) будем также рассматривать показатель степени посредничества, которая для каждой вершины равна числу проходящих через нее кратчайших путей между другими вершинами. Этот показатель отражает «важность при распространении информации» участника сообщества (Батура, 2012: 20).

Центральные по посредничеству вершины сосредоточились в основном в кластере 1 и - заметно в меньшем количестве - в кластере 0 .

Также в четырех наиболее крупных кластерах были изучены профили десяти пользователей с наибольшей степенью, т. е. наибольшим количеством друзей в графе. Среди таких наиболее популярных профилей можно отметить преобладание спортивных и культурных деятелей, а также различных услуг, в том в сфере культуры.

Кластер 0, похоже, включает наибольшее количество известных публичных лиц и их подписчиков, в их числе известный лама буддийского храма «Цеченлинг» Буян Сандык (Буян башкы), депутат Верховного Хурала Республики Тыва, известный общественник и спортсмен Седен-Очур Кара-Сал, общественник, активист движения «Субедей» Кара-Хаан Кара-Сал и другие. Кластеры 1 и 2 включают профили государственных и общественных объединений, предложения услуг и известных лиц, а также их подписчиков. Среди них ВК-профиль Правительства Республики Тыва ${ }^{1}$, газета «Молодежь Тувы»², эстрадная артистка Борбаана Баржай, поэтесса, драматург Чаяна Чыкай и другие. 
Можно предположить, что данное сообщество стало одной из доступных форм коммуникации пользователей, сравнительно мало связанных друг с другом родственными и иными отношениями.

«Сарыг Шажын Тывада» является одним из немногих сравнительно гомогенных по этническому и языковому составу буддийских сообществ, в котором состоят преимущественно этнические тувинцы. Следует отметить при этом, что, при относительной этнической гомогенности, данное сообщество включает также представителей иных этнических групп.

На основе построенного социального графа можно сделать вывод о том, что для пользователейтувинцев, в том числе находящихся за пределами Республики Тыва, данное сообщество является одним из ключевых каналов получения информации о тувинском буддизме. Также существенным отличием от подобных сообществ, ориентированных на бурятских и калмыцких пользователей, «Сарыг Шажын Тывада», за редким исключением, ведется на тувинском языке. Интересен эффект трансляции в данном, буддийском сообществе популярности не связанных напрямую в своей деятельности с буддийскими общинами пользователей, среди которых известные политики, общественные деятели, представители сферы культуры и даже профили объединений.

\section{Заключение}

Пользователи ВКонтакте могут обнаружить большое разнообразие «буддийских» групп самой разной направленности. Можно согласиться с Х. Кэмпбэлл, что в социальных сетях проявляется ключевая характеристика цифровой религии как взаимовлияния интерактивности, наполняемой пользователями онлайн-культуры и традиционных религиозных сообществ, с исторически укорененными ритуалами и верованиями (Campbell, 2013: 4).

В целом, в буддийских онлайн-сообществах происходят процессы формирования новых форм социального взаимодействия, обладающих существенными отличиями от традиционных институтов монастырской организации, образования, монашества. В социальных сетях традиционное буддийское духовенство оказалось в условиях конкуренции со стороны буддистов-мирян и вызова прежней легитимности. С другой стороны, различия между офлайн общинами транслируются в онлайн-пространство и приобретают форму лишь частично пересекающихся сообществ, в которых по-разному воспроизводятся буддийские идеи и практики.

Исследование тувинских онлайн-сообществ ВКонтакте также демонстрирует перенос сложной структуры буддийских общин и организаций в социальные сети. Наличие крупных сообществ, таких как «Сарыг Шажын Тывада», одного из крупнейших буддийских групп в ВКонтакте, служит доказательством приверженности многих тувинских пользователей буддийским ценностям и идеям, проявлением их буддийской идентичности. При этом тувинские буддийские онлайн-сообщества обладают выраженными этнорелигиозными отличиями, ориентацией на воспроизводство этнической традиции, использование тувинского языка, сравнительно высокой плотностью социальной коммуникации. Можно предположить, что для многих пользователей участие в таких онлайн-группах выступает одним из механизмов трансляции этничности и приверженности традициям.

\section{СПИСОК ЛИТЕРАТУРЫ}

Актамов, И. Г., Бадмацыренов, Т. Б., Цыремпилов, Н. В. (2015) Российский буддизм в интернет-измерении // Власть. № 7. С. 125-130.

Актамов, И. Г., Бадмацыренов, Т. Б., Хандаров, Ф. В. (2018) Особенности развития виртуальных буддийских сообществ Рунета // Власть. № 2. С. 100-105.

Бадмацыренов, Т. Б., Скворцов, М. В., Хандаров, Ф. В. (2018а) Буддийские цифровые практики трансцендентности: VK-сообщество «Хамбо Лама Даши-Доржо Итигэлов» // Мониторинг общественного мнения: экономические и социальные перемены. № 2 (144). C. 338-361. DOI: https://www.doi.org/10.14515/monitoring.2018.2.18

Бадмацыренов, Т. Б., Скворцов, М. В., Хандаров, Ф. В. (2018b) Топологические характеристики буддийского сообщества в социальной сети «ВКонтакте» // Социологические исследования. № 8. С. 74-82. DOI: https://www.doi. org/10.31857/S013216250000756-4

Базаров, Б. В. (2014) Буддизм и вызовы XXI века // Вестник Бурятского научного центра Сибирского отделения Российской академии наук. № 3 (15). С. 12-16.

Батура, Т. В. (2012) Методы анализа компьютерных социальных сетей // Вестник Новосибирского государственного университета. Серия: Информационные технологии. Т. 10. Вып. 4. С. 13-28.

История буддизма в СССР и Российской Федерации в 1985-1999 гг. (2011) / под общ. ред. Н. Г. Очировой. Элиста : Министерство образования, культуры и науки Республики Калмыкия. 392 с. 
Ламажаа, Ч. К. (2010) Клановость в политике регионов России: Тувинские правители. СПб. : Алетейя. 208 с.

Монгуш, М. В. (2001) История буддизма в Туве (вторая половина VI - конец XX в.). Новосибирск: Наука. 200 с.

Тарбастаева, И. С. (2018) Буддийские ценности как возможная экономическая детерминанта развития тувинского общества // Новые исследования Тувы. № 2. С. 95-111. DOI: https://www.doi.org/10.25178/nit.2018.2.5

Тензин, Ч. М.-Х. (2018) Буддизм в духовной жизни тувинского общества // Вестник Бурятского государственного университета. № 3. T. 1. C. 87-93. DOI: https://www.doi.org/10.18101/1994-0866-2018-1-3-87-93

Уланов, М. С. (2008) О причинах распространения буддизма на Западе в эпоху глобализации // Вестник Волгоградского государственного университета. Серия 7: Философия. Социология и социальные технологии. № 2 (8). С. $68-72$. 177 c.

Хомушку, О. М. (1998) Религия в истории культуры тувинцев. М. : Институт этнологии и антропологии РАН.

Campbell, H. (2016) Surveying theoretical approaches within digital religion studies // New Media and Society. Vol. 19, issue 1. P. 1-10. DOI: https://doi.org/10.1177/1461444816649912

Campbell, H. (2010) When Religion meets New Media. New York : Routledge. 232 p. $288 \mathrm{p}$.

Campbell, H. (2013) (ed.) Digital Religion: Understanding Religious Practice in New Media Worlds. London : Routledge.

Campbell, H., Evolvi, G. (2020) Contextualizing current digital religion research on emerging technologies // Human Behavior and Emerging Technologies. Vol. 2, issue 1. P. 5-17. DOI: https://doi.org/10.1002/hbe2.149

Connelly, L. (2015) Toward a Typology and Mapping of the Buddhist Cyberspace // Buddhism, the Internet, and Digital Media: The Pixel in the Lotus / G. P. Grieve, D. Veidlinger (eds.). New York : Routledge. 240 p. P. 58-78.

Grieve, G. P., Veidlinger, D. (2016) Buddhist Media Technologies // The Oxford Handbook of Contemporary Buddhism / M. Jerryson (ed.) New York : Oxford University Press. 760 p. P. 469-483.

Helland, C. (2005) Online religion as lived religion methodological issues in the study of religious participation on the Internet [Электронный ресурс] // Online - Heidelberg Journal of Religions on the Internet. Vol. 01.1 Special Issue on Theory and Methodology. P. 1-16. URL: http://archiv.ub.uni-heidelberg.de/volltextserver/5823/1/Helland3a.pdf (дата обращения: 12.09.2020).

Newman, M. E. J. (2003) Mixing patterns in networks // Physical Review E. Vol. 67. No 2. DOI: https://doi.org/10.1103/ PhysRevE.67.026126

Newman, M. E. J., Barabasi, A., Watts, D. J. (2006) The Structure and Dynamics of Networks: (Princeton Studies in Complexity). Princeton, USA : Princeton University Press. 592 p.

O'Leary, S. (1996) Cyberspace as sacred space: Communicating religion on computer networks // Journal of the American Academy of Religion. № 64. P. 781-808.

Ostroumova-Prokhorenkova, L., Krot, A. (2016) Assortativity in Generalized Preferential Attachment Models // Algorithms and Models for the Web Graph. Proceedings of the 13th International Workshop, WAW 2016, Montreal, QC, Canada, December 14-15, 2016. / A. Bonato, G. Fan Chung, P. Pralat (eds.). Cham: Springer International Publishing. P. 9-21. DOI: https://www.doi.org/10.1007/978-3-319-49787-7

Prebish, Ch. S. (1979) American Buddhism. North Scituate : Duxbury Press. 220 p.

Prebish, Ch. S. (2004) The Cybersangha: Buddhism on the Internet // Religion online: Finding faith on the Internet / L. L. Dawson, D. E. Cowan (eds.). London : Routledge. 288 p. P. 135-151.

Ray, G. (1994) A Resource Roundup for the Cybersangha // Tricycle: The Buddhist Review. 3(4). P. 60-63.

Religion and cyberspace (2005) / Hojsgaard, M., Warburg, M. (eds.). New York : Routledge. 224 p.

Rheingold, H. (1993) The Virtual Community. New York : Harper Perennial. 325 p.

Schaeffer, S. E. (2007) Graph clustering // Computer science review. T. 1. №. 1. P. 27-64.

Schlutter, M. (2014) Buddhism in the Digital World // The Wiley Blackwell Companion to East and Inner Asian Buddhism / M. Poceski (ed.) Chichester, UK: John Wiley. 535 p. P. 505-522.

\section{REFERENCES}

Дата поступления: 20.10.2020 2.

Aktamov, I. G., Badmatsyrenov, T. B. and Tsyrempilov, N. V. (2015) Rossiiskii buddizm v internet-izmerenii [Buddhism in Russia in the Internet dimension]. Vlast', no. 7, pp. 125-130. (In Russ.).

Aktamov, I. G., Badmatsyrenov, T. B., Khandarov, F. V. (2018) Osobennosti razvitiia virtual'nykh buddiiskikh soobshchestv Runeta [The peculiarities of the virtual Buddhist communities development in the Runet]. Vlast', no. 2, pp. 100-105. (In Russ.).

Badmatsyrenov, T. B., Skvortsov, M. V., Khandarov, F. V. (2018a) Buddiiskie tsifrovye praktiki transtsendentnosti: VK-soobshchestvo «Khambo Lama Dashi-Dorzho Itigelov» [Buddhist digital practices of transcendence: VK community "Hambo Lama Dashi-Dorzho Itigilov"]. Monitoring of Public Opinion: Economic and Social Changes, no. 2 (144), pp. 338-361. (In Russ.). DOI: https://www.doi.org/10.14515/monitoring.2018.2.18

Badmatsyrenov, T. B., Skvortsov, M. V., Khandarov, F. V. (2018b) Topologicheskie kharakteristiki buddiiskogo soobshchestva v sotsial'noi seti «VKontakte» [Topological characteristics of the Buddhist Community in the VKontakte 
social network]. Sotsiologicheskie issledovaniia, no. 8, pp. 74-82. (In Russ.). DOI: https://www.doi.org/10.31857/ S013216250000756-4

Bazarov, B. V. (2014) Buddizm i vyzovy XXI veka [Buddhism and the challenges of the Third millenium]. Vestnik Buriatskogo nauchnogo tsentra Sibirskogo otdeleniia Rossiiskoi akademii nauk, no. 3 (15), pp. 12-16. (In Russ.).

Batura, T. V. (2012) Metody analiza komp'iuternykh sotsial'nykh setei [Methods of social networks analysis]. Vestnik Novosibirskogo gosudarstvennogo universiteta. Seriia: Informatsionnye tekhnologii, vol. 10, issue 4, pp. 13-28. (In Russ.).

Istoriia buddizma $v$ SSSR i Rossiiskoi Federatsii $v$ 1985-1999 gg. [The history of Buddhism in the USSR and the Russian Federation in 1985-1990] (2011) / ed. by. N. G. Ochirova. Elista, Ministerstvo obrazovaniia, kul'tury i nauki Respubliki Kalmykiia. 392 p. (In Russ.).

Lamazhaa, Ch. K. (2010) Klanovost'v politike regionov Rossii. Tuvinskie praviteli [The clan politics of Russia's regions. The Leaders Of Tuva]. St. Petersburg, Aleteiia. 208 p. (In Russ.).

Mongush, M. V. (2001) Istoriya buddizma v Tuve (vtoraya polovina VI - konets XX v.) [The History of Buddhism in Tuva (latter half of the 6th - late 20th cc.)]. Novosibirsk, Nauka. 200 p. (In Russ.).

Tarbastaeva, I. S. (2018) Buddiiskie tsennosti kak vozmozhnaia ekonomicheskaia determinanta razvitiia tuvinskogo obshchestva [Buddhist values as a potential economic determinant in the development of Tuvan society]. New Research of Tuva, no. 2, pp. 95-111. (In Russ.). DOI: https://www.doi.org/10.25178/nit.2018.2.5

Tenzin, Ch. M.-Kh. (2018) Buddizm v dukhovnoi zhizni tuvinskogo obshchestva [Buddhism in the spiritual life of Tuvan society]. BSU bulletin. Philosophy, no. 3, vol. 1, pp. 87-93. (In Russ.). DOI: https://www.doi.org/10.18101/1994-0866-20181-3-87-93

Ulanov, M. S. (2008) O prichinakh rasprostraneniia buddizma na Zapade v epokhu globalizatsii [Causes of Buddhism's spread in the West in the epoch of globalization]. Vestnik Volgogradskogo gosudarstvennogo universiteta, Issue 7: Filosofiia. Sotsiologiia i sotsial'nye tekhnologii, no. 2 (8), pp. 68-72. (In Russ.).

Khomushku, O. M. (1998) Religiia v istorii kul'tury tuvintsev [Religion in the history of Tuvan culture]. Moscow, Institut etnologii i antropologii RAN. 177 p. (In Russ.).

Campbell, H. (2016) Surveying theoretical approaches within digital religion studies. New Media and Society, vol. 19, issue 1, pp. 1-10. DOI: https://doi.org/10.1177/1461444816649912

Campbell, H. (2010) When Religion meets New Media. New York, Routledge. 232 p.

Campbell, H. (2013) (ed.) Digital Religion: Understanding Religious Practice in New Media Worlds. London, Routledge. $288 \mathrm{p}$.

Campbell, H. and Evolvi, G. (2020) Contextualizing current digital religion research on emerging technologies. Human Behavior and Emerging Technologies, vol. 2, issue 1, pp. 5-17. DOI: https://doi.org/10.1002/hbe2.149

Connelly, L. (2015) Toward a Typology and Mapping of the Buddhist Cyberspace. In: Buddhism, the Internet, and Digital Media: The Pixel in the Lotus / G. P. Grieve, D. Veidlinger (eds.). New York, Routledge. 240 p. P. 58-78.

Grieve, G. P. and Veidlinger, D. (2016) Buddhist Media Technologies. In: The Oxford Handbook of Contemporary Buddhism / M. Jerryson (ed.) New York, Oxford University Press. 760 p. P. 469-483.

Helland, C. (2005) Online religion as lived religion methodological issues in the study of religious participation on the Internet. Online - Heidelberg Journal of Religions on the Internet, vol. 01.1 Special Issue on Theory and Methodology, pp. 1-16 [online] Available at: http://archiv.ub.uni-heidelberg.de/volltextserver/5823/1/Helland3a.pdf (access date: 12.09.2020).

Newman, M. E. J. (2003) Mixing patterns in networks. Physical Review E, vol. 67, no 2. DOI: https://doi.org/10.1103/ PhysRevE.67.026126

Newman, M. E. J., Barabasi, A. and Watts, D. J. (2006) The Structure and Dynamics of Networks: (Princeton Studies in Complexity). Princeton, USA, Princeton University Press. 592 p.

Ostroumova-Prokhorenkova, L. and Krot, A. (2016) Assortativity in Generalized Preferential Attachment Models. In: Algorithms and Models for the Web Graph. Proceedings of the 13th International Workshop, WAW 2016, Montreal, QC, Canada, December 14-15, 2016 / A. Bonato, G. Fan Chung, P. Pralat (eds.). Cham, Springer International Publishing. Pp. 9-21. DOI: https://www.doi.org/10.1007/978-3-319-49787-7

Prebish, Ch. S. (1979) American Buddhism. North Scituate, Duxbury Press. 220 p.

Prebish, Ch. S. (2004) The Cybersangha: Buddhism on the Internet. In: Religion online: Finding faith on the Internet / L. L. Dawson, D. E. Cowan (eds.). London, Routledge. 288 p. Pp. 135-151.

Ray, G. (1994) A Resource Roundup for the Cybersangha. Tricycle: The Buddhist Review, no. 3(4), pp. 60-63.

Religion and cyberspace (2005) / Hojsgaard, M., Warburg, M. (eds.). New York, Routledge. 224 p.

Rheingold, H. (1993) The Virtual Community. New York, Harper Perennial. 325 p.

Schaeffer, S. E. (2007) Graph clustering. Computer science review, vol. 1, no. 1, pp. 27-64.

Schlutter, M. (2014) Buddhism in the Digital World. In: The Wiley Blackwell Companion to East and Inner Asian Buddhism / M. Poceski (ed.) Chichester, UK: John Wiley. 535 p. Pp. 505-522. 